TAO, Vol. 16, No. 2, 331-343, June 2005

\title{
A Refined Historical Record of Volcanic Eruptions around Taiwan: Tectonic Implications in the Arc-continent Collision Area
}

\author{
Chang-Hwa Chen ${ }^{1, *}$ and Jason Jiun-San Shen ${ }^{1}$ \\ (Manuscript received 7 May 2004, in final form 16 February 2005)
}

\begin{abstract}
The historical record of volcanic eruptions is extremely important for natural hazard reduction, especially in densely inhabited areas. In concert with clarification of contradictory points in the historical eruptions' record, we have modified the locality, eruption size, and timing of submarine volcanic eruptions around Taiwan.

Three out of five submarine eruption records (catalog numbers 080104, 0801-05 and 0802-01) in northern offshore Taiwan can be clearly traced. These events indicate that volcanic activity in this area is still in progress; and hence a program for volcanic hazard reduction should be seriously considered in northern Taiwan.

Two events (catalog numbers 0801-03 and 0801-02) shown to have occurred in the southeast offshore region of Taiwan appear to be related to the Eurasian Continental Plate's eastwardly subduction under the Philippine Sea Plate. However, the new seismic wave travel time tomography of the subduction zone will be needed to clarify this.

The refined results shall contribute to the Smithsonian Institution's Global Volcanism Program and the International Association of Volcanology and Chemistry of the Earth's Interior (IAVCEI) for editing the next version of the Catalog of Active Volcanoes of the World.
\end{abstract}

(Key words: Volcanic Eruption, Taiwan, Ryukyu Arc, Luzon Arc)

\footnotetext{
${ }^{1}$ Institute of Earth Sciences, Academia Sinica, Taipei, Taiwan, ROC

* Corresponding author address. Dr. Chang-Hwa Chen, Institute of Earth Sciences, Academia Sinica, Taipei, Taiwan, ROC; E-mail: china@earth.sinica.edu.tw
} 


\section{INTRODUCTION}

The historical record of active volcanic eruption is extremely important for natural hazard reduction, especially in densely populated areas. Five historical submarine eruptions in the offshore Taiwan region have been reported in different documents (Kuno 1962). The earliest report was in 1853, some 150 years ago. In recent decades, three nuclear power plants (NPPs) have been built and one is currently under construction in both the southern and northern regions of Taiwan Island. Moreover, the shoreline of Taiwan is heavily populated and industrialized. With this in mind, a tangible record of submarine volcanic eruptions around Taiwan is extremely important in making natural hazard assessments, especially for the NPPs safety assessment (Chen and Shen 2004).

The purpose of this paper is to clarify any contradictory points in the historical eruptions' record around Taiwan, based on the original records and recent research results. The tectonic implications of these volcanic activities are also discussed in the final section of this paper. The refined record of historical eruptions shall contribute to the Smithsonian Institution's Global Volcanism Program and the International Association of Volcanology and Chemistry of the Earth's Interior (IAVCEI) to improve the next version of the Catalog of Active Volcanoes of the World.

\section{RESULTS}

Five historical submarine eruptions around offshore Taiwan have been reported (Simkin and Siebert 1994) (Fig. 1). The eruption records were traced back to their original sources as completely as possible. These records were actually written in four languages, Deutsh, French, Japanese, and English, respectively. Moreover, catalog numbers of each eruption event in this paper shall reflect those in the Volcanoes of the World (Simkin and Siebert 1994). The refined results of five historical records around Taiwan are described as follows:

\subsection{Catalog Number: 0801-05}

Historical Record:

Locality: $26^{\circ} 11^{\prime} 2^{\prime \prime} \mathrm{N}, 122^{\circ} 27^{\prime} 30^{\prime \prime} \mathrm{E}$

Time: April 18, 1916

Description: The Japanese Navy boat named "Akitusima" reported a steam eruption over about $30 \mathrm{~m}^{2}$ in 10 minutes (Omori 1918; Kuro 1962).

Comment:

The eruption type and period was described, but no eruptive solid material was reported. Therefore, the activity was believed to be small and short. The VEI (Volcanic Explosivity Index, Newhall and Self 1982) should be estimated as 0. In addition, there was no record to indicate this eruption extended to 1927 (Simkin and Siebert 1994). 


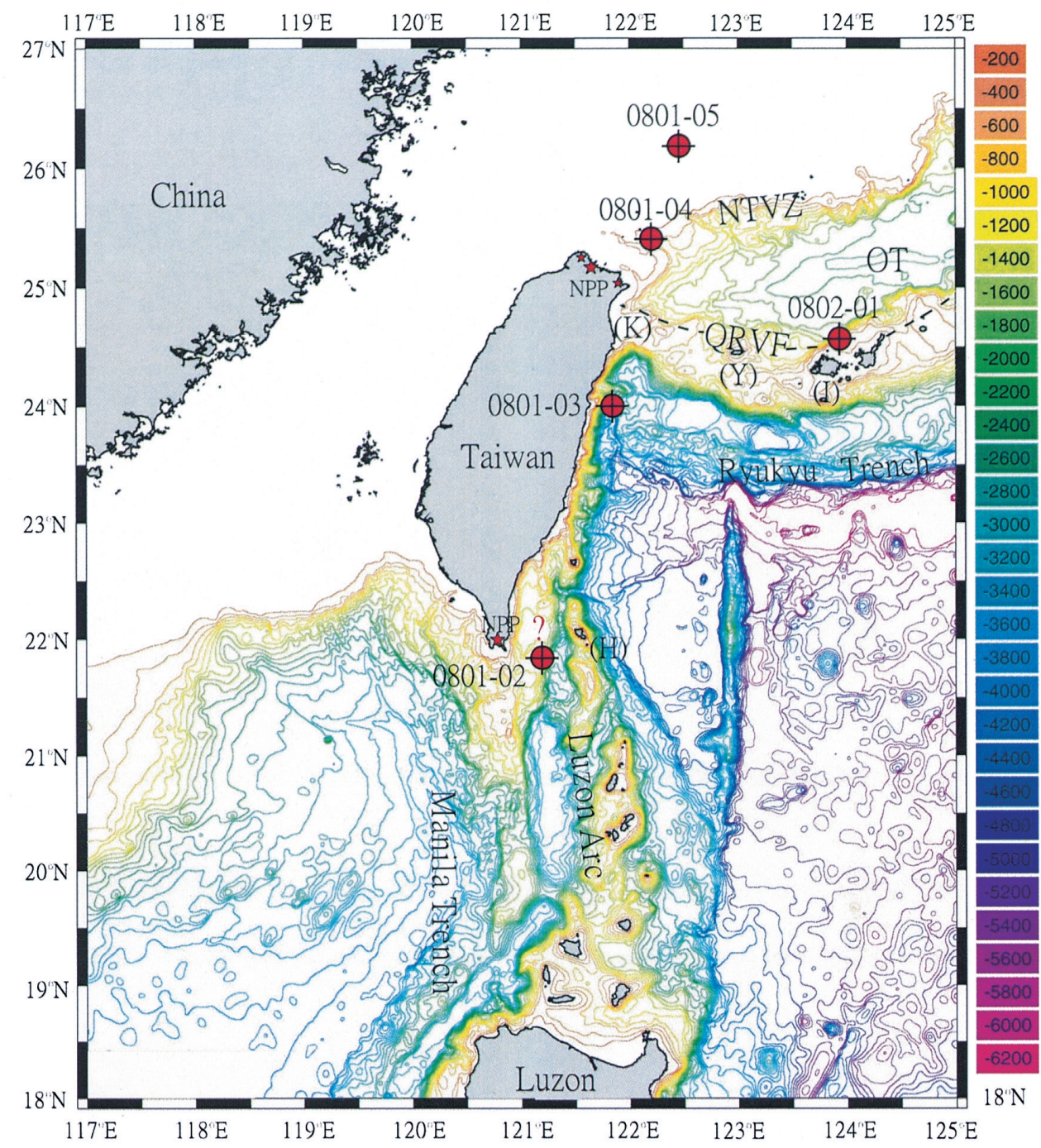

Fig. 1. The localities of historical volcanic eruptions around the arc-continent collision area - offshore Taiwan. The bathymetric map by the National Center for Ocean Research, Taiwan is followed. The catalog numbers of eruptions are consistent with those in the Volcanoes of the World (Simkin and Siebert 1994). Abbreviations are as follows: QRVF: the Quaternary Ryukyu Volcanic Front; NTVZ: the Northern Taiwan Volcanic Zone; OT: the Okinawa Trough; NPP: nuclear power plant; K: Keishantao island; Y: Yonaguni island; I: Irimote island and $\mathrm{H}$ : Hsiaolanhsu island. 


\subsection{Catalog Number: 0801-04}

Historical Record:

Locality: $25.4^{\circ} \mathrm{N}, 122.2^{\circ} \mathrm{E}\left(25^{\circ} 24^{\circ} \mathrm{N}, 122^{\circ} 12^{`} \mathrm{E}\right)$

Time: 1867

Description: none

Comment:

The 0801-04 eruption locality in the catalogs of Kuro (1962) and Simkin and Siebert (1994), both, were referred from Sapper $(1917,1927)$, but locality of this event in above catalogs showed the different positions, $25^{\circ} 25^{\prime} \mathrm{N}, 122^{\circ} 20^{\prime} \mathrm{E} ; 25.42^{\circ} \mathrm{N}, 122.33^{\circ} \mathrm{E}$, respectively. Whereas Sapper $(1917,1927)$ recorded that the locality of the $0801-04$ event was $25.4^{\circ} \mathrm{N}, 122.2^{\circ} \mathrm{E}$, the locality of the event 0801-04 in the catalogs of Kuro (1962) and Simkin and Siebert (1994) should be corrected.

\subsection{Catalog Number: 0801-03}

Historical Record:

Locality: $24^{\circ} 00^{`} \mathrm{~N}, 121^{\circ} 50^{\circ} \mathrm{E}$

Time: October 29, 1853

Description: smoke columns and ash over several days (Perrey 1858).

Comment:

The submarine eruption was qualitatively described by the Lieutenant "Boyle" of the American Navy boat, "Southampton". This submarine eruption was reported to have formed columns of smoke about $18 \mathrm{~km}$ (10 nautical miles) offshore from Taiwan, no lava, however, was observed (Perrey 1858). Several days later, another boat named "Macedonian" passed by the same location and reported white ash covering its curtains (Perrey 1858). The time of eruption was clearly recorded (Perrey 1858). However, in both the Kuro (1962) and Simkin and Siebert (1994) catalogs, the timing of this event has not been reported exactly.

\subsection{Catalog number: 0801-02}

Historical Record:

Locality: offshore from the southern most point of Taiwan

Time: January 15, 1854

Description: none

Comment:

This record revealed the most contradictory points regarding locality and eruption descriptions (Sapper 1917, 1927; Kuro 1962; Simkin and Siebert 1994). According to the boat, 
"Susquehannah", as it passed the southernmost point of Taiwan on January 15, 1854, two small volcanoes were observed (Perrey 1858). Unfortunately, the author did not describe the precise location and eruption phenomenon. The locality of this event was only marked on Map Plate XXXI (Sapper 1927); however, Kuro (1962) found that it was not consistent with the text, as the locality was not mentioned (Sapper 1927). Yet, Kuro (1962) does mention a precise locality of this event as $21^{\circ} 50^{\prime} \mathrm{N}, 121^{\circ} 11^{\circ} \mathrm{E}$. Further investigation of another original record source (Fuchs 1865), did not indicate the locality of this event either. Hence, we conclude that this eruption record cannot be treated as robust.

\subsection{Catalog Number: 0802-01 (Japan)}

Historical Record:

Locality: $24^{\circ} 34^{\circ} \mathrm{N}, 123^{\circ} 56^{\circ} \mathrm{E}$

Time: October 31, 1924

Description: Water domes were formed and lapilli ejected. On the second day, a field of pumice 3 nautical miles $(\sim 5.6 \mathrm{~km})$ long, 0.5 nautical miles $(\sim 0.9 \mathrm{~km})$ wide, and $90 \mathrm{~cm}$ high, covered the eastern sea of Iriomote Island (Tanakadate 1931; Kuro 1962), and the pumice drifted with the Kuroshiro current to the main islands of Japan (Tanakadate 1931; Japan Meteorological Agency 1975).

Comment:

The record is reliable and clear. However, the date of eruption should be 1924 as per the original report, not in 1925 (Kuro 1962; Tanakadate 1931). The VEI value is estimated at 2 $\left(5600 \mathrm{~m} * 900 \mathrm{~m} * 0.9 \mathrm{~m}=4.54 \times 10^{6} \mathrm{~m}^{3}\right)$. Another Japanese Navy boat, "Nogima Tokumu Kan" found a wide pumice floating on the sea surface around the Yonaguni Island on December 19, 1924 (Journal Geological Society Japan 1925). The duration of the eruption was conservatively estimated to be at least 50 days, because pumice floating on the sea surface around the eruption area should have been readily dispersed with the strong Kuroshiro current to the main islands of Japan (Tanakadate 1931). It is possible to assume from this information that the eruption size of this event could be much larger than previously estimated.

\section{TECTONIC IMPLICATIONS}

The Philippine Sea Plate is converging toward Taiwan at about $7 \mathrm{~cm} \mathrm{yr}^{-1}$ in a northwestsoutheast direction (Seno 1977). There are two subduction zones dipping in opposite directions occurring to the northeast and southeast of Taiwan (Fig. 2) (Ho 1982). To the southeast, the Eurasian Continental Plate is subducting beneath the Philippine Sea Plate along the Manila Trench (Lin et al. 1999). To the northeast, the Philippine Sea Plate is subducting below the Eurasian Continental Plate along the Ryukyu Trench. The island of Taiwan was built up by an oblique collision of the Luzon Arc, riding on the Philippine Sea Plate, against the passive continental margin from $10 \mathrm{Ma}$ (Teng 1990). 


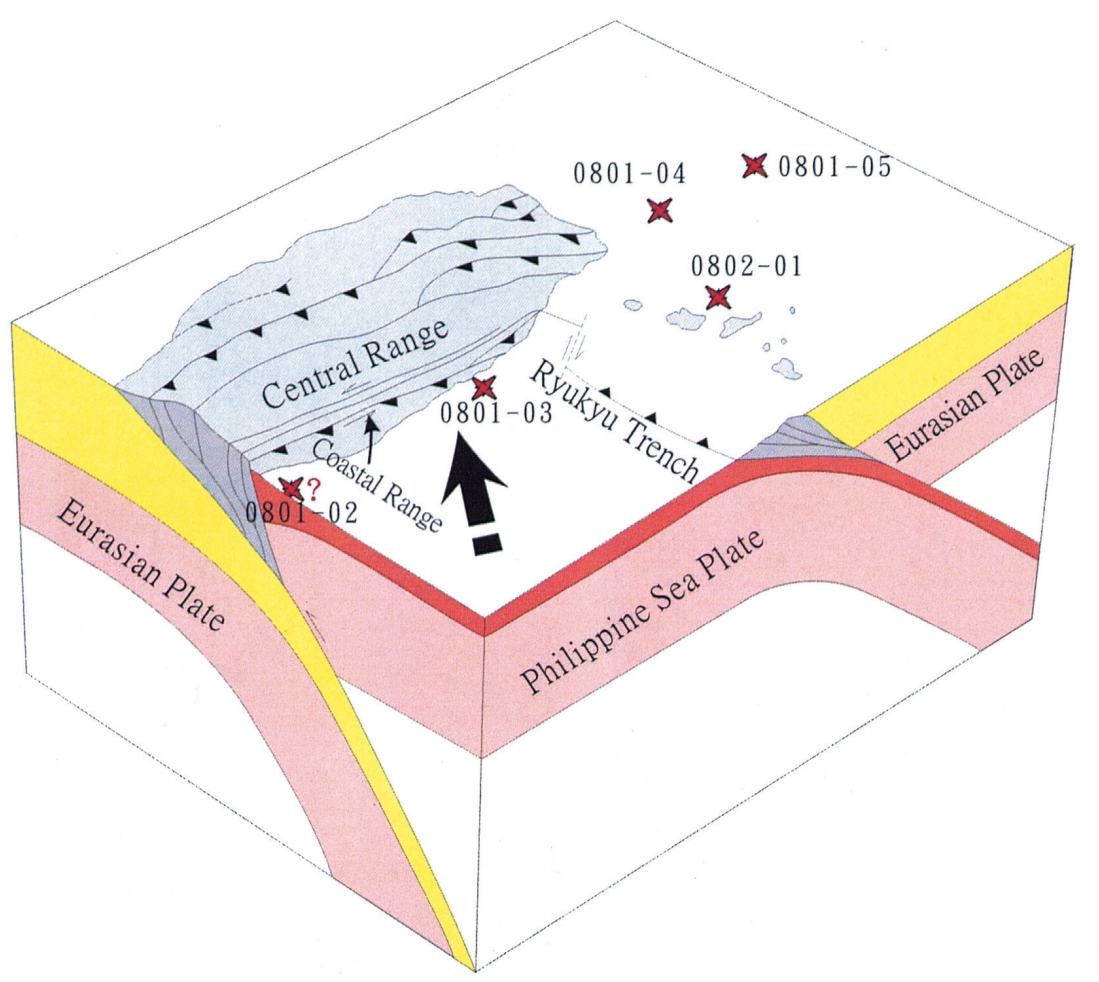

Fig. 2. Schematic diagram of plate tectonic setting of Taiwan (Adopted from Ho 1982). The catalog numbers of submarine eruptions are same with those in Fig. 1.

The localities of volcanic eruptions, Catalog numbers 0801-03 and 0801-02 (noted latter with highly uncertainty), at southeastern offshore Taiwan lie in the region of the Taiwan Luzon Arc from the Philippines. From the dating results of volcanic islands in the northern part of the Taiwan - Luzon Arc, the youngest age appeared in Hsiaolanhsu was around $20 \mathrm{Ka}$ (Yang et al. 1995), which position is close to that of Catalog number 0801-02. As known, this Hsiaolanhsu volcanic activity could conceivably have occurred as the northern Taiwan - Luzon Volcanic Arc of the Eurasian Continental Plate eastwardly subducted under the Philippine Sea Plate (Figs. 1 and 2) (Lin et al. 1999). If the Catalog number 0801-3 event could be proposed as the northern propagation of the active Taiwan - Luzon arc, this active arc chain will be completely different with the Coastal Range of the old Taiwan - Luzon arc, which activities ceased at 2.2 Ma due to arc-continent collision (Lo et al. 1994; Yang et al. 1995). However, advanced studies of volcanic juveniles and submarine geographies of these two eruptions are definitely required. Moreover, seismic wave travel time tomography should be applied to image this subduction zone in central and southern Taiwan, such as with the work conducted for the islands of Honshu and Kyushu in Japan (Zhao et al. 1992, 2000). 
The Ryukyu subduction system, composed of the Quaternary Ryukyu Volcanic Front (QRVF), the Ryukyu Trench and the Okinawa Trough, extends from southwestern Kyushu in the north to northeastern Taiwan in the south (Figs. 2 and 3). The Okinawa Trough has an obvious extensional back arc basin relation to the Ryukyu arc (Lee et al. 1980). The volcanic activities in northern inland and offshore Taiwan (called Northern Taiwan Volcanic Zone, NTVZ) behind the Okinawa Trough began about 2.8 Ma (Wang and Chen 1990).

Teng (1996) proposed that volcanic activity in the NTVZ behind the Okinawa Trough was terminated, when the Okinawa Trough opening migrated to the east due to a mountain collapse after the arc-continent collision. However, an alternative model has been suggested that the QRVF and the NTVZ have different magma generation mechanisms (Chen 1997; Chen et al. 1995, 1999; Wang et al. 1999, 2004) (Fig. 3). The mechanism for magma generation of the latter should not be closely related with the subduction, from the viewpoint of geochemical concepts and dating results. This model suggests that the major magma source of the NTVZ is derived from the products of asthenosphere upwelling under the lithospheric extensional environment after the arc-continent collision in northern Taiwan and the offshore area. Based on the modeling propositions, volcanic activities in these two volcanic zones are continuous.

The sites of Catalog numbers 0801-04 and 0801-05 in northern offshore Taiwan are located in the NTVZ, and the location of Catalog number 0802-01 is on the QRVF line (Fig. 3). These three historical eruptions are, at least, consistent with the latter model proposing that new magma generation in the NTVZ and QRVF is still in progress. The frequency of volcanic activity in the NTVZ and the QRVF can be confidently estimated as a hundred year time scale. This result indicates the critical importance of understanding local conditions for volcanic hazard assessment in northern Taiwan.

It is worthily pointed out that there was a magnitude 7.0 earthquake which occurred on December 18, 1867 (Tsai 1985). This earthquake generated a high tsunami wave that drowned several hundred people along the northern coast of Taiwan. The offshore epicenter of this earthquake was assessed as $25.3^{\circ} \mathrm{N}, 121.7^{\circ} \mathrm{E}$ (Tsai 1985). In fact, the position and time of Catalog number 0801-04's eruption was quite coincidental with this earthquake record. Although there has been no evidence available to peruse the relationship between those two events, we know for sure that geological activity along the offshore area of northeastern Taiwan often occurs and potentially causes geological catastrophes.

\section{CONCLUSIONS}

The locality, eruption size, and timing of eruptions in the historical records around Taiwan were modified and discussed. Two events (catalog numbers 0801-03 and 0801-02) shown at southeastern offshore Taiwan likely have significant tectonic meaning, where volcanic activities could have occurred as the result of the Eurasian Continental Plate's eastwardly subduction under the Philippine Sea Plate.

Discussing the contradictory points of the historical eruptions' record around Taiwan, three (catalog numbers 0801-04, 0801-05 and 0802-01) of five submarine eruption records 


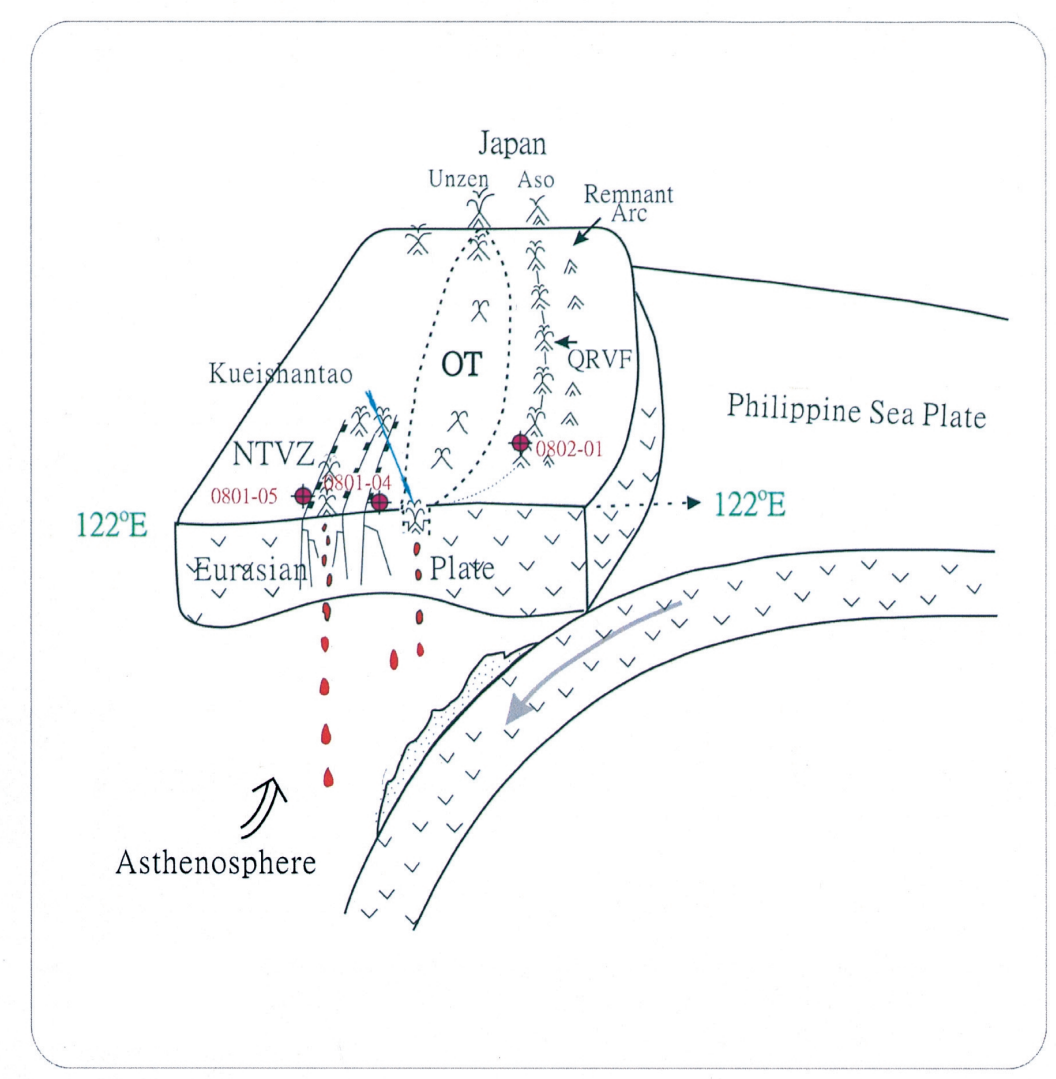

Fig. 3. The eruption localities in northern offshore Taiwan with the relative tectonic settings (modified from Chen et al. 1995). The traverse diagram exhibits the different tectonic setting of the northern Taiwan Volcanic Zone (NTVZ), Okinawa Trough (OT) and Quaternary Ryukyu Volcanic Front (QRVF). The magma generation of the NTVZ was related to rifting. The tectonic evolution and magma variations in the NTVZ were discussed in detail by Chen (1997), Chen et al. $(1995,1999)$ and Wang et al. (1999, 2004).

can be clearly traced, which are consistent with the tectonic model of the island's arc and structures, the NTVZ and the QRVF, respectively. These three records strongly suggest that new magmatic activity in northern offshore Taiwan is still present. Therefore, a program of the volcanic hazard reduction should be seriously considered in northern Taiwan.

Acknowledgments The senior author is deeply indebted to Prof. Takemura of Kyoto University and Miss Chen, Librarian of the IES who helped in searching for the original references. 
Drs. Lee J. C. and Lowemark L. of the IES helped to translate the French and Deutsh records and Miss Ku Y. P. helped with the art work. Valuable comments were made by Dr. Lin C. H. in the preparation of this paper. Authors would like to thank the referees for their constructive comments and suggestions. This work was supported by the IES, Academia Sinica, Kyoto University, Japan, and National Science Council, R.O.C. (NSC91-2116-M-001-022 and NSC922116-M-001-013).

\section{REFERENCES}

Chen, C. H., 1997: Comment on "Extensional collapse of the northern Taiwan mountain belt" by Louis S. Teng. Geology, 20, 855-856

Chen, C. H., C. H. Chen, S. A. Mertzman, and J. J.- S. Shen, 1999: An unusual late Cenozoic volcanic zone in northern Taiwan- behind southern Okinawa Trough. J. Geol. Soc. China, 42, 593-612.

Chen, C. H., T. Lee, Y. N. Shieh, and C. H. Chen, 1995: Magmatism at the onset of back arc basin spreading in Okinawa Trough. J. Volcanol. Geotherm. Res., 69, 313-322.

Chen, C. H., and J. J. S. Shen, 2004: Discussions on "the IAEA Guidelines for Assessing Volcanic Hazards at Nuclear Facilities". J. Volcanol. Geotherm. Res., 134, 339-342.

Fuchs, S. W. C., 1865: Die Vulkanishen Erscheinungen. Leiptzig \& Heidelberg, 46. (in Deutsh)

Ho, C. S., 1982: Tectonic evolution of Taiwan: Explanatory text of the tectonic map of Taiwan. Ministry Economic Affairs, ROC, $126 \mathrm{pp}$

Japan Meteorological Agency, 1975: National catalogue of the active volcanoes in Japan. 110.

Journal Geological Society Japan, 1925: 32, 39. (in Japanese)

Kao, H., and R. J. Rau, 1999: Detailed structures of the subducted Philippine Sea Plate beneath northeast Taiwan: A new type of double seismic zone.J. Geophys. Res., 104, 1015-1033.

Katsui, Y., 1971: List of the World Active Volcanoes. Volcanic Society of Japan Draft ms, limited circulation, 69-70.

Kuro, H., 1962: Japan, Taiwan and Mariana, Catalogue of the active volcanoes of the world including solfatara fields, Napoli. International Association of Volcanology, 1-5.

Lee, C. S., G. G. Jr. Shor, L. D. Bibee, R. S. Lu, and T. W. C. Hilde, 1980: Okinawa Trough: Origin of a back arc basin. Marine Geol., 35, 219-241.

Lin, C. H., B. S. Huang, and R. J. Rau, 1999: Seismological evidence for a low-velocity layer within the subducted slab of southern Taiwan. Earth Planet. Sci. Lett., 174, 231-240.

Lo C. H., T. C., Onstott, C. H. Chen, and T. Lee, 1994: An assessment of 40Ar/39Ar dating for the whole-rock volcanic samples from Luzon arc near Taiwan. Chem. Geol., 114, 157-178.

Newhall C. G., and S. Self, 1982: The volcanic explosivity index (VEI): an estimate of explosive magnitude for historical volcanism. J. Geophys. Res., 87, 1231-1238. 
Omori, F., 1918: Historical sketches of the volcanic eruptions in Japan, Part 1, Report Imperial Earthquake Investigation Committee, 86, 213. (in Japanese)

Perrey, Alexis, 1858: Note sur les tremblements de terre en 1856, avec supplements Pour les annees anterieures. 32-33. (in French)

Sapper, K., 1917: Katalog der geschichtlichen Vulkanausbruche. Strassburg, 149. (in Deutsh)

Sapper, K., 1927: Vulkankunde. Stuttgart, 320. (in Deutsh)

Seno T., 1977: The instantaneous rotation vector of the Philippine Sea plate relative to the Eurasian plate. Tectonophys., 42, 209-226.

Simkin, T., and L. Siebert, 1994: Volcanoes of the World. Geoscience Press, Tucson, 85.

Tanakadate, H., 1931: Volcanic activity in Japan and vicinity during the period between 1924 and 1931. Japanese J. Astronomy Geophy., 9, 47-64.

Teng, L. S., 1990: Geotectonic evolution of late Cenozoic arc-continent collision in Taiwan. Tectonophys., 183, 57-76.

Teng, L. S., 1996: Extensional collapse of the northern Taiwan mountain belt.Geology, 24, 949-952.

Tsai, Y. B., 1985: A study of disastrous earthquakes in Taiwan 1683-1895. Bull. Inst. Earth Sci., Academia Sinica. 1-44

Wang, K. L., S. L. Chung, C. H. Chen, R. Shinjo, T. F. Yang, and C. H. Chen, 1999: Postcollisional magmatism around northern Taiwan and its relation with opening of the Okinawa Trough. Tectonophys., 308, 363-376.

Wang, K. L., S. L. Chung, S. Y. O’Reilly, S. S Sun, R. Shinjo, R., and C. H. Chen, 2004: Geochemical constraints for the genesis of post-collisional magmatism and the geodynamic evolution in the northern Taiwan region. J. Petrol., 45, 975-1011.

Wang W. S., and C. H. Chen, 1990: The volcanology and fission track age dating of pyroclastic deposits in Tatun volcano group, northern Taiwan. Acta Geologica Taiwanica, 28, $1-30$.

Yang T. F., J. L. Tien, C. H. Chen, T. Lee and R. S., Punongbayan, 1995: Fission-track dating of volcanics in the northern part of the Taiwan-Luzon arc: eruption ages and evidence for the crustal contamination. J. Southeast Asian Earth Sci., 11, 81-93.

Zhao, D., A. Hasegawa, and S. Horiuchi, 1992: Tomograpic imaging of $\mathrm{P}$ and $\mathrm{S}$ wave velocity structure beneath northeastern Japan. J. Geophys. Res., 97, 19909-19928.

Zhao D., K. Asamori, and H. Iwamori, 2000: seismic structure and magmatism of the young Kyushu subduction zone. Geophys. Res. Lett., 27, 2057-2060. 


\section{Appendix:}

The original historical records of volcanic eruptions around Taiwan:

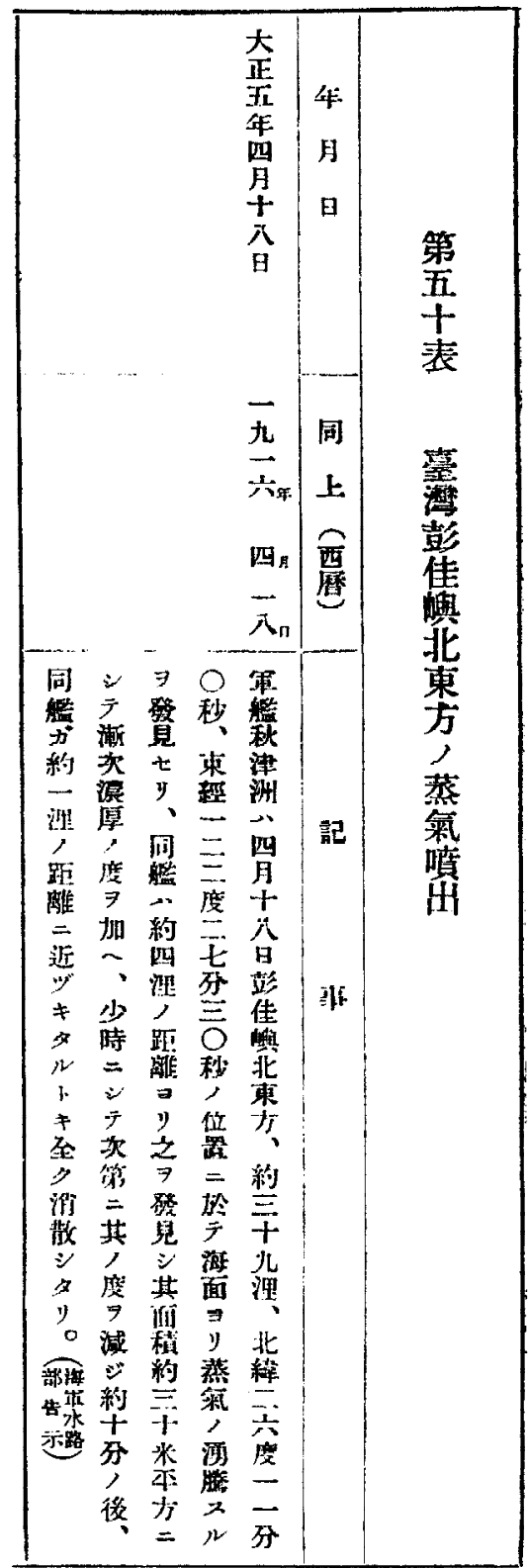

A-1. The Catalog number 0801-05: record source from the Historical sketches of the volcanic eruptions in Japan, Part 1, Report Imperial Earthquake Investigation Committee, 86, p. 213 (Omori 1918) (in Japanese). 
Geräusche, Blasen- und ungewohnliche Wellenbildung erkennen. Eigentliche Ausbruche sind freilich nicht bekannt. Dagegen hat nach Noaks MS.-Zusammenstellung ${ }^{1}$ ) 1867 ein unterseeischer Ausbruch in $25,4^{\circ} \mathrm{NBr}$, und $122,2^{\circ}$ ÖL. stattgefunden.

A-2. The Catalog number 0801-04: record source from Katalog der geschichtlichen Vulkanausbruche, p. 149 (Sapper 1917) (in Deutsh).

$3 \mathrm{~A}$

- Le 29, par 24. lat. N. et $121^{\circ} 30^{\prime}$ long. E. (de Gr.?), le Southampton, de la marine américaine, apereut un volean sous-marin en pleine activité à 10 milles de Formose. a Les colonnes de fumée, dit le lieutenant Boyle, s'élevaient à une hauteur extraordinaire, et tout le phénomène me rappelait celui dont javais été :émoin sur les còtes de Sicile lor's de l'apparition de l'île Julia; seulement le spectacle était plus imposant et l'éruption plus violente, quoique, à cause des nuages de fumée, aucun courant de lave ne fùt visible. La profondeur de l'eau était ici beaucoup plus considérable que sur les côtes de Sicile, et cette profondeur seule aurait

3B

sufli pour empécher de voir la lave n la vigie, placée dans les hunes, erut d'abord que ces manifestations étaient dues à un navire à vapeur. Le Macedomian, qui passa dans cet endroit quelque jours après le Southampton, ent son pont et toutes ses voiles couverts d'une cendre blanche.

- Dans le courant de septembre, à Tiflis (Géorgie), secousse de 7 sceondes de durée.

- 16 novembre, à San Jose (Californie), me secousse légère.

Le 25, a San Franciseo, une secousse.

- Le 22, $51 / 2$ h. du soir, a Buitenzorg (Java), une secousse.

- 11 déecmbre, à San Francisco et Mission Dolores, une légére secousse.

Le 25, à Shasta City (Californic), une secousse légère.

- Le 29, a Bex (Vaud), une secousse.

1854. - I5 janvier, le Susquehannah doubla la pointe sud de

Formose et observa de petits voleans dans deux endroits.

A-3A and 3B. The catalog numbers 0801-03 and 0801-02: record source from Note sur les tremblements de terre, en 1856, Avec supplements pour les annees anterieures, p.32-33 (Perrey 1858) (in French). 
No. 11

VOLCANIO ACTITTY IN JAPAN ETC.

Bublarine eruptox dear Hatoma Istand.

1925. On Sejutember 31 , a great submarine eruption was witnessed in the vicinity of Hatoma Island of the Yneyama group. The turbid sen water was greatly ngitated, particularly in the ertuptive center. With every eruptive spa:m, a large water column rose high above the sea surface hurling pumiceons lajilli from the top. On this day, clouds veiled the scene of the erujution so completely that it was impossible to determine the exuct site of the erujtion. The next day, an entensive pumice field, three sen-miles in length, lanlf a sen-mile in breadth, and about $90 \mathrm{~cm}$. in height, alpenred on the sen surface near to the east of Nisiomotesima.

A-4. The Catalog number 0802-01: record source from Japanese J. Astromony Geophysics, 9, p.61 (Tanakadate 1931). 